\title{
Effect of the addition of calcium chloride and different storage temperatures on the post-harvest of jabuticaba variety Pingo de Mel
}

\author{
Lismaíra Gonçalves Caixeta GARCIA ${ }^{1}$ Edson Pablo da SILVA², Carlos de Melo e SILVA NETO²,
} Eduardo Valério de Barros VILAS BOAS ${ }^{4}$, Eduardo Ramirez ASQUIERI ${ }^{5}$, Clarissa DAMIANI ${ }^{5}$, Flávio Alves da SILVA ${ }^{5 *}$

\begin{abstract}
The objective of this study was to analyze the effect of different calcium chloride concentrations on the post-harvest conservation of jabuticaba variety Pingo de $\mathrm{Mel}$ at different storage temperatures. The fruit were collected 30 days after the anthesis and subjected to immersions in calcium chloride solution at different concentrations $(0 \%, 2 \%, 4 \%$, and $6 \%)$ for 30 minutes at room temperature. Then, the fruit were dried and packed in polypropylene bags and incubated in a chamber at different temperatures $\left(6{ }^{\circ} \mathrm{C}, 12^{\circ} \mathrm{C}\right.$, and $\left.25^{\circ} \mathrm{C}\right)$. Samples were analyzed at time 0 and every two days, up to 12 days of storage. No effect of different calcium chloride concentrations was observed in the fruit characteristics at different storage temperatures over time. During storage, an increase of soluble and total pectin contents, antioxidant activity, $\mathrm{CO}_{2}$, total sugars, acidity, and weight loss was observed. Higher storage temperatures affected both the increase in weight loss, $\mathrm{pH}$, and $\mathrm{O}_{2}$ production and the reduction of vitamin C content. Refrigeration was important for the post-harvest conservation of jabuticaba variety Pingo de Mel, once the fruit stored at $6{ }^{\circ} \mathrm{C}$ suffered minor variations with improvements or little changes during the 12 days.
\end{abstract}

Keywords: antioxidants; respiration rate; vitamin C; weight loss.

Practical Application: Studying the post-harvest shelf life of jabuticaba fruits to improve its commercialization.

\section{Introduction}

Jabuticaba tree is originally from Minas Gerais and widely cultivated in almost all Brazilian regions, from the State of Para to Rio Grande do Sul, in addition to other countries such as Bolivia, Argentina, Uruguay, and Peru. It produces fruit once or more rarely twice a year, usually between August and November. Its fruit have a dark peel, ranging from purple to black and whitish pulp, with a sweet and slightly sour taste. Jabuticaba fruit have a high commercial potential, being used to make sweets, juices, ice cream, yogurts, jams, vinegar, liquor, wine, among others (Ascheri et al., 2006; Wu et al., 2012).

Although Jabuticaba is a fruit appreciated worldwide, it has a limited market due to its high perishability, which affects the production and commercialization. After harvesting, the fruit lasts for up to three days, followed by changes in appearance, due to the intense water loss, deterioration, and fermentation of the pulp, thus affecting the commercialization of fruit in natura (Lima et al., 2008).

During the post-harvest of tropical fruit, several chemical and physical changes occur due to internal and external factors, thus special care is required at all stages of the production chain (from producer to consumer). Rapid maturation demands special handling technology and justifies the small export volume for most of these products.
Jabuticaba, as well as other native fruit, along with fruit from the same botanical family (Myrtaceae), such as gabiroba (Campomanesia adamantium Camb) (Melchior et al., 2006), cagaita (Eugenia desynterica DC.) (Carneiro et al., 2015), and araça (Psidium spp.) (Drehmer \& Amarante, 2008) are considered regional food delicacies, with great potential for production and commercialization throughout the country. However, these fruit exhibit intense respiration rates when mature, leading to quality decline of fresh fruit.

Cold storage is one of the most widely used methods for conservation of fruit and vegetables. However, appropriate technologies that combine post-harvest with the refrigeration temperature are necessary to preserve fruit quality for longer periods (Martins et al., 2007).

Treatment with calcium along with low temperatures has a high commercial potential to improve the nutritional quality of fruit and vegetables. Calcium can increase postharvest shelf life by maintaining fruit firmness, reducing respiration rate, and ethylene production, delaying fruit ripening, increasing aroma synthesis (Chen et al., 2011).

Therefore, the aim of this study was to evaluate the effect of different calcium chloride concentrations, associated with 
different storage temperatures on the postharvest shelf life of jabuticabas variety 'Pingo de Mel'.

\section{Materials and methods}

\subsection{Raw material}

The experiment was performed in September 2015, during the peak season, at the Farm and Winery Jabuticabal in Nova Fatima, district of Hidrolandia-GO, located in the geographical coordinates $16^{\circ} 55^{\prime} 32.35^{\prime \prime}$ south latitude and $49^{\circ} 21^{\prime} 39.76^{\prime \prime}$ west longitude, $35.6 \mathrm{~km}$ from Goiânia-GO. Seventy trees were selected at random, homogeneous as to the size $( \pm 2 \mathrm{~m})$ and age (10 years), and branches were marked at the time of anthesis. Harvest began in the 30 days after anthesis, and the fruit were collected in the morning and selected for the presence of defects or pests.

\subsection{Experimental design}

In the laboratory, the jabuticabas were washed with running water and sanitized with sodium hypochlorite solution at $150 \mu \mathrm{L} . \mathrm{L}^{-1}$ for 15 minutes. Then, they were immersed in calcium chloride solution at different concentrations $(0 \%, 2 \%, 4 \%$, and $6 \%)$ for 30 minutes at room temperature. Subsequently, the fruit were dried using a centrifuge, and packed in $250 \mathrm{~mL}$ polypropylene ( $100 \mathrm{~g}$ fruit) bags and stored in the chamber at different temperatures $\left(6^{\circ} \mathrm{C}, 12^{\circ} \mathrm{C}\right.$, and $25^{\circ} \mathrm{C}$ ). The samples were analyzed at time zero and every two days, up to twelve days (T0, T2, T4, T6, T8, T10, and T12), by means of analysis of color, firmness, respiration rate, weight loss, $\mathrm{pH}$, titratable acidity, total and soluble pectin, vitamin, total sugars and antioxidante activity, carrying out four replicates with 3 readings each, totaling 12 readings for each time analyzed (T0, T2, T4, T6, T8, T10, and T12). However, not all treatments lasted the twelve days of storage, because in some treatments the fruits deteriorated before the 12 days.

\subsection{Determinations}

\section{Color measurements}

The color determination was performed by reading the color parameters defined by the CIEL ${ }^{\star} a^{\star} b^{\star}$ system. The parameters $\mathrm{L}^{*}, \mathrm{a}^{*}$, and $\mathrm{b}^{\star}$ were measured in the colorimeter (Hunterlab, ColorQuest II), in which $\mathrm{L}^{*}$ defines brightness $\left(\mathrm{L}^{\star}=0\right.$ black and $\mathrm{L}^{\star}=100$ white), and $\mathrm{a}^{*}$ and $\mathrm{b}^{*}$ define the chromaticity $\left(+\mathrm{a}^{\star}=\right.$ red and $-\mathrm{a}^{\star}=$ green; $+\mathrm{b}^{\star}=$ yellow and $-\mathrm{b}^{\star}=$ blue $)$.

\section{Firmness}

Firmness was determined using a texture analyzer (TA-XT Plus, Surrey, England) using a P/2 probe, with pre-test, test, and post-test speed of $2 \mathrm{~mm} . \mathrm{s}^{-1}, 2 \mathrm{~mm} . \mathrm{s}^{-1}$ and $10 \mathrm{~mm} \cdot \mathrm{s}^{-1}$, respectively, at a penetration distance of $6 \mathrm{~mm}$. Firmness was expressed in Newton (N).

\section{Respiration rate}

The respiration rate was measured using the Dräger Simultan Test $\mathrm{CO}_{2}$ equipment by injecting the needle into the closed bags. The measurement was performed rapidly inside the chamber to prevent changes in the storage temperature. After measurements, the "holes" were capped with silicone so that the gas transfer inside the bags was not affected.

\section{Weight loss}

The fresh weight loss was determined by the difference between the initial weight and the weight on the day of sampling and expressed as a percentage.

\section{pH and titratable acidity}

The $\mathrm{pH}$ was determined using a digital potentiometer (Tecnal, TEC 3P-MP). The apparatus was calibrated with $\mathrm{pH} 4.0$ and 7.0 buffer, and direct readings were performed through the immersion of the electrode into the sample, according to the methodology of Association of Official Analytical Chemists (2010). Titratable acidity was determined by titration with $0.01 \mathrm{~N}$ sodium hydroxide $(\mathrm{NaOH})$ using $1 \%$ phenolphthalein as indicator, according to Association of Official Analytical Chemists (2010).

\section{Total and soluble pectin}

Total and soluble pectins were extracted as described by McCready \& McComb (1952), and determined colorimetrically by the reaction with carbazole, as reported by Bitter \& Muir (1962). The total and soluble pectins were expressed as mg of galacturonic acid $100 \mathrm{~g}^{-1}$ fruit.

\section{Vitamin C}

The vitamin $\mathrm{C}$ content was determined by the colorimetric method as described by Strohecker \& Henning (1967). Vitamin $\mathrm{C}$ was extracted with oxalic acid, filtered, and determined using 2,4-dinitrophenylhydrazine and ascorbic acid as standard. The reading was performed in a spectrophotometer (Biospectro SP-220) at 520nm, and the results were expressed as $\mathrm{mg}$ of ascorbic acid per 100 grams sample.

\section{Total sugars}

The total sugars content was determined in a spectrophotometer at $620 \mathrm{~nm}$ by the anthrone method and expressed as gram of glucose per $100 \mathrm{~g}$ sample (Dische, 1962).

\section{Obtaining the extracts for determination of in vitro antioxidant activity}

To obtain the extracts, the samples (pulp and peel) were homogenized with ethyl ether in the ratio 1:20 (w/v) under stirring and protected from light for one hour. Subsequently, the extracts were filtered through Whatman filter paper \# 1 , and the volumes were adjusted. The extract was dried on filter paper for 2 hours at $35^{\circ} \mathrm{C}$ to evaporate the ethyl ether residue. Then, the residue was weighed into a beaker and ethanol was added in the ratio of 1:20, and the extraction process (stirring+filtration) was repeated. After filtration, the residue was kept on filter paper for 30 minutes at $50{ }^{\circ} \mathrm{C}$ to evaporate the residual solvent. Finally, water in the ratio of 1:20 was added to the residue from the previous extracts to obtain the aqueous extract, which was kept 
under stirring and protected from light for one hour. The extracts were stored in amber glass bottles at $-18^{\circ} \mathrm{C}$ until determination of the bioactive compounds.

\section{Antioxidant activity in vitro}

The antioxidant activity was determined in all extracts (ether, ethanol, and aqueous) by the iron reduction method (FRAP - Ferric Reducing Antioxidant Power), according to Pulido et al. (2000) with modifications by Rufino et al. (2006). Readings (tripyridyl triazine ferrous complex) were measured in a spectrophotometer at $595 \mathrm{~nm}$ (Biospectro SP-220), and the results were expressed as $\mu \mathrm{mol} \mathrm{Fe}_{2} \mathrm{SO}_{4} \cdot \mathrm{g}^{-1}$ of fresh weight.

The antioxidant activity by the ABTS ${ }^{+}$radicals method was determined according to Rufino et al. (2007). The absorbance was measured in a spectrophotometer (BiospectroSP-220) at $734 \mathrm{~nm}$ after 6 minutes of the addition of $\mathrm{ABTS}^{+}$. The results were expressed as $\mu \mathrm{mol}$ Trolox. $\mathrm{g}^{-1}$ fresh weight.

\section{Statistical analysis}

The calcium chloride solutions at different concentrations $(0 \%, 2 \%, 4 \%$, and $6 \%)$ and temperatures $\left(6^{\circ} \mathrm{C}, 12^{\circ} \mathrm{C}\right.$, and $\left.25^{\circ} \mathrm{C}\right)$ were considered for principal component analysis (PCA). Over 12 days of storage, The parameters fruit weight, $\mathrm{pH}$, titratable acidity, total and soluble pectins, vitamin $\mathrm{C}$, total sugars, and antioxidant activity in vitro (ABTS •+ and FRAP) were compared within the treatments. Data were normalized and correlated to compare the parameters of different unit of measurement (Melo et al., 2015).

The same treatments and parameters used in PCA were subjected to multiple regression analysis with a significance level of $95 \%$. To observe the relationship between the variables, the regression coefficient $\left(\mathrm{R}^{2}\right)$ of the model and the linear regression coefficient were determined. To analyze the relationship between the variables temperature and storage time and the

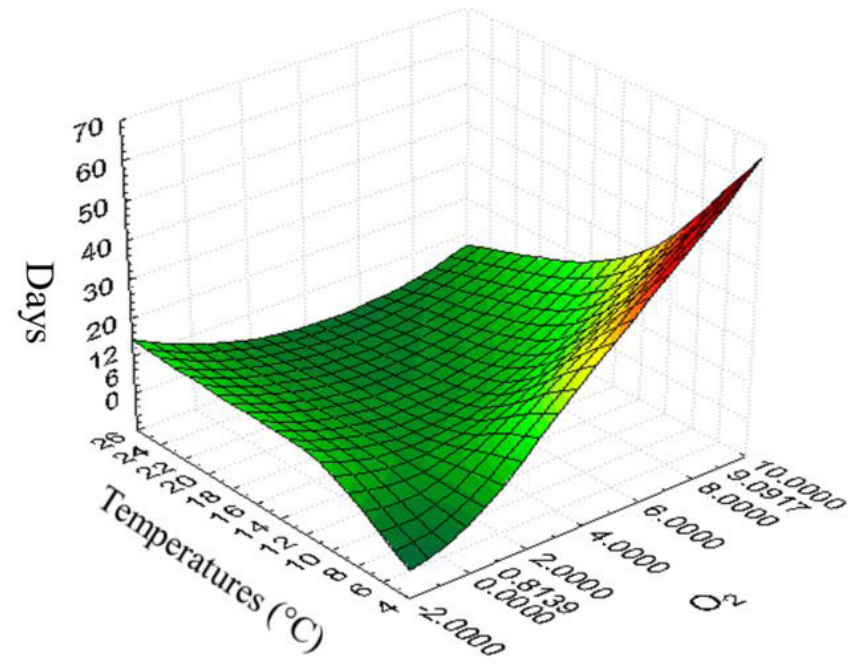

fruit parameters, response surface graphs were constructed, considering the polynomial adjustment of the variables.

\section{Results and discussion}

In relation to the respiration rate $\left(\mathrm{CO}_{2}\right.$ and $\left.\mathrm{O}_{2}\right)$ of jabuticaba variety 'Pingo de Mel', changes were observed with the increase in storage temperature (from $6^{\circ} \mathrm{C}$ to $25^{\circ} \mathrm{C}$ ), with a reduction in $\mathrm{CO}_{2}$ concentrations and an increase in $\mathrm{O}_{2}$ levels (Figure 1 and Appendix A - Table 1A), which may favor fruit degradation. According to Chitarra \& Chitarra (2005), respiration stands out as the main physiological phenomenon that most affects the conservation and quality of fruit and vegetables after harvest. The low temperature decreases the respiration rate, in addition to providing slower metabolism, increasing the shelf life and, consequently, maintaining post-harvest quality for longer periods. Velho et al. (2011) analyzed the effect of storage temperature on the postharvest quality of Highland guavas (Accasellowiana (O. Berg.) Burret), and also observed an increase in the respiration rate of fruit with increasing temperature, leading to a shorter shelf life, as also observed in the jabuticabas of the present study.

No effect of the different calcium chloride concentrations $(0 \%, 2 \%, 4 \%$, and $6 \%)$ was observed in the maintenance of fruit characteristics at different storage temperatures $\left(6^{\circ} \mathrm{C}, 12^{\circ} \mathrm{C}\right.$, and $25^{\circ} \mathrm{C}$ ), probably due to the thickness of the peel of Jabuticaba variety 'Pingo de Mel', which did not allow the permeabilization of calcium chloride. Calcium can penetrate fruit directly through the epidermis and/or by natural cuticle cracks (Conway et al., 1992), however the fruit of jabuticaba presents a very smooth and homogeneous epidermis, which may have made this penetration difficult. Longer immersion times result in greater absorption, but, Mota et al. (2002) investigated the immersion of jabuticaba variety 'Sabará' in $\mathrm{CaCl}_{2} 40 \mathrm{~g} \cdot \mathrm{L}^{-1}$ for $0,5,10,20$, 40 , and 60 minutes, and found a reduction of firmness at all immersion periods studied, with an increase in both the weight loss of fresh fruit and acidity values, corroborating the present

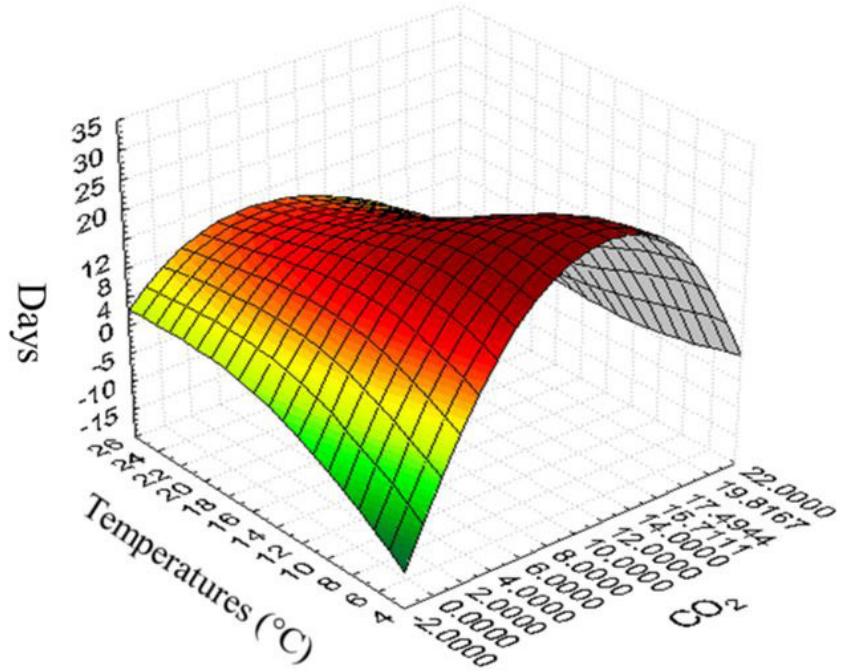

Figure 1. Mean values of the respiration rate $\left(\mathrm{CO}_{2}\right.$ and $\left.\mathrm{O}_{2}\right)$ of jabuticaba fruit 'Pingo de Mel', stored at different temperatures $\left(6^{\circ} \mathrm{C}, 12^{\circ} \mathrm{C}\right.$, and $\left.25^{\circ} \mathrm{C}\right)$, during storage (0 to 12 days). 
data. Thus, studies on higher immersion times are required, as well as higher $\mathrm{CaCl}_{2}$ concentrations, to evaluate the effectiveness of calcium chloride on the post-harvest shelf life of jabuticaba.

One of the major postharvest problems is moisture loss, followed by weight loss. However, in the present study, these two variables were in the same quadrant (Figure 2 and Appendix A - Table 1A), showing no effect of one over the other, which is a positive factor for the post-harvest of jabuticaba variety 'Pingo de Mel', once water loss results in wilting, causing consumers' rejection at the time of purchase.

Silva et al. (2015) analyzed the influence of the treatment with calcium chloride in papaya and observed that in all treatments the fruits showed progressive loss of fresh mass during the storage period, corroborating in this way with the results of this work that showed that the loss of mass was not significantly influenced by the application of calcium chloride solutions. Differently from the data found in the present study, Sanches et al. (2017), analyzing pitanga (Eugenia uniflora L.), observed that calcium chloride at concentrations of $1 \%$ and $2 \%$ resulted in lower mass loss over time. According to Azzolini et al. (2004), the excess of calcium salts in the solution applied on the fruit can cause dehydration, so the fact that calcium chloride did not influence the loss of mass in the present study can be justified by the fact that it was used more concentrated solutions of calcium chloride.

Kays (1997) reported that the weight loss in fruit may be largely associated with water loss through transpiration and, to a lesser extent, respiration, which increases when fruit are exposed to higher temperatures. This fact was observed in the present study, once the higher the storage temperature, the greater the weight loss. Thus, the storage temperature of $6{ }^{\circ} \mathrm{C}$ led to the lowest weight loss in jabuticaba variety 'Pingo de Mel' throughout the storage, as shown in Figure 3A and Appendix A - Table 1A. Brunini \& Coelho (2004) studied the effect of packages associated with different temperatures in jabuticaba variety 'Sabará and observed that the fruit stored at room temperature $\left(21^{\circ} \mathrm{C}\right.$ to $\left.26.5^{\circ} \mathrm{C}\right)$ exhibited the highest fresh weight losses, as also observed in the present study.

The increase in temperature also influenced the reduction of firmness of the fruit (Figure 3B and Appendix A - Table 1A), since the weight loss contributes to the lower firmness. Regarding the storage period, jabuticaba presented greater firmness in the second day of storage, which decreased afterward. In addition, an increase in soluble and total pectin contents was observed throughout the storage, corroborating with the firmness data.

Higher titratable acidity values were observed during storage, with a reduction in $\mathrm{pH}$ (Figures 2 and $3 \mathrm{C}$ and Appendix $\mathrm{A}$ - Table 1A). According to Chitarra \& Chitarra (2005), pH tends to decrease with increasing acidity only at acid concentrations ranging from $2.5 \%$ to $0.5 \%$, as observed in the present study. In addition, the temperature affected the titratable acidity, once the higher acidity values were observed in the fruit stored at lower temperatures $\left(6{ }^{\circ} \mathrm{C}\right)$. Typically, acidity tends to decrease in the course of storage, as the acids are converted to sugars, as observed in fruit such as passion fruit (Passiflora edulis Sims f. flavicarpa Deg.) variety 'Afruvec' (Arruda et al.,

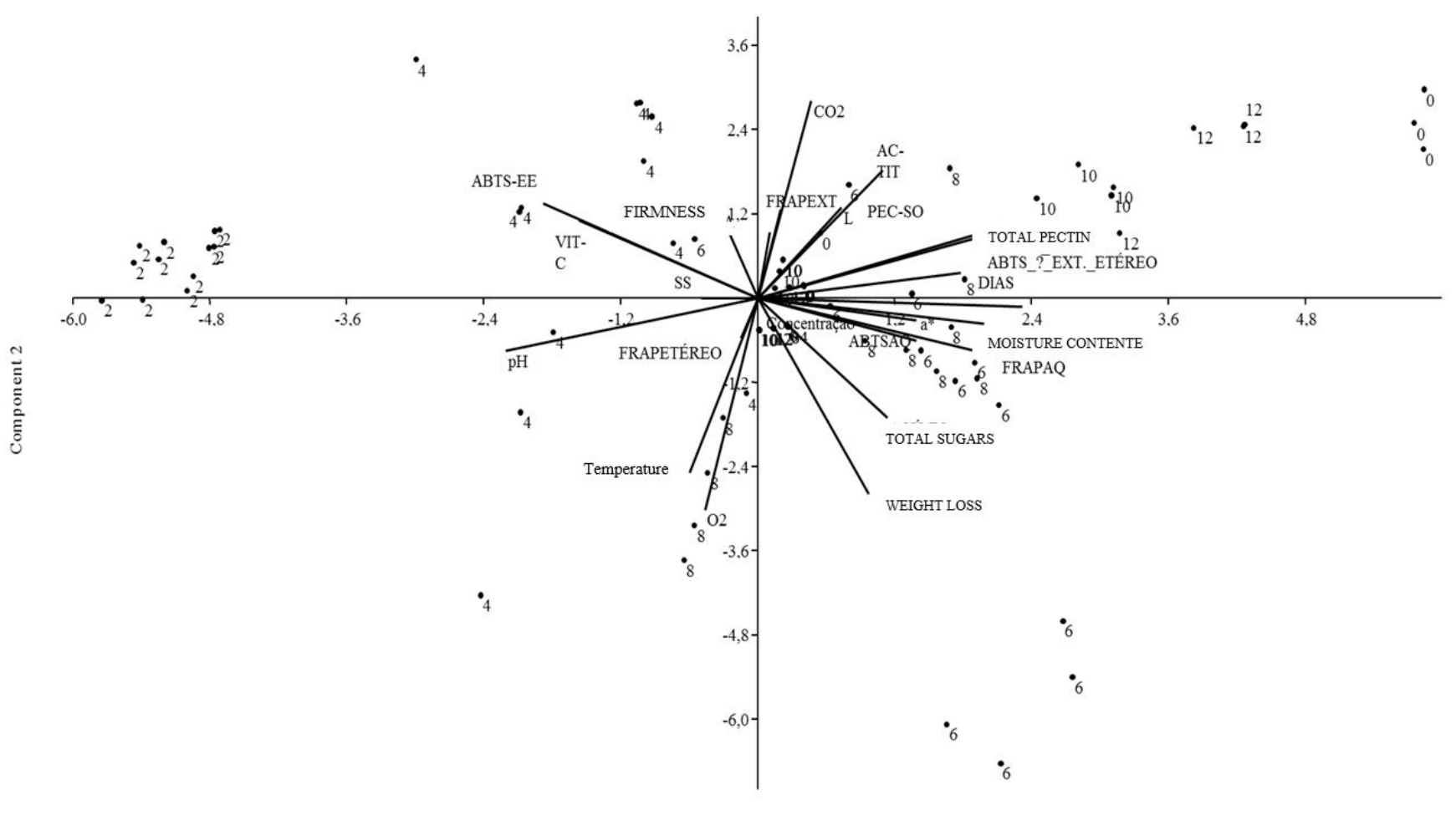

Component 1

Figure 2. Principal component analysis for the storage time ( 0 to 12 days), calcium chloride concentrations ( $0 \%, 2 \%$, $4 \%$, and $6 \%)$, storage temperatures $\left(6^{\circ} \mathrm{C}, 12{ }^{\circ} \mathrm{C}\right.$, and $\left.25^{\circ} \mathrm{C}\right)$ and morphophysiological parameters of jabuticaba variety 'Pingo de Mel'. 
2011), bilimbi (Averrhoa bilimbi L.) (Souza et al., 2009), peach (Prunus persica L.) cultivar 'Maciel' (Barreto et al., 2016), among others. However, acidity may increase in some fruit, as observed in the present study, and the study by Vilas Boas (2002) in banana and pineapple, with the highest acidity levels in the full ripening stage. Damiani et al. (2008) have also found an increase in acidity in minimally processed pequi and stated that this

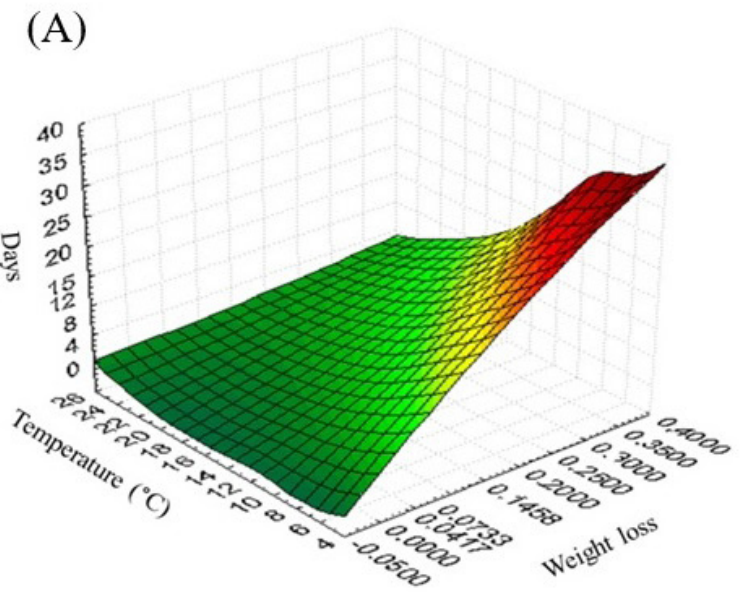

(C)

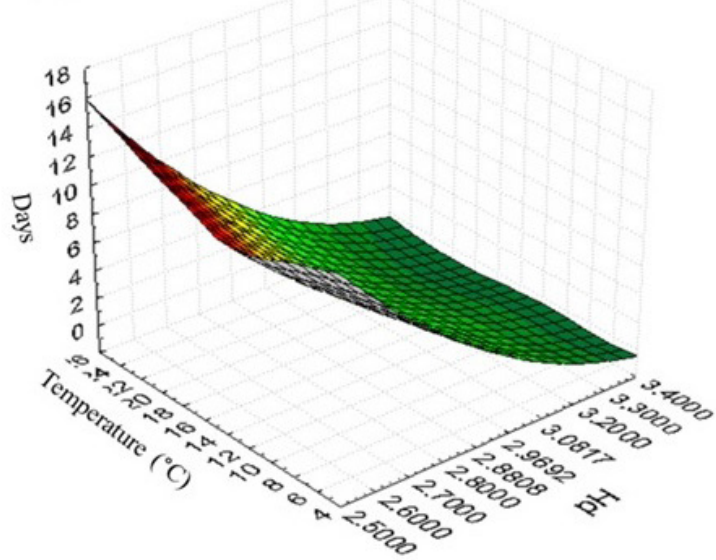

behavior is due to the low respiration metabolism, interrupted by the storage temperature, which generates accumulation of acids in the vacuoles.

Through the PCA, it was possible to observe an increase in total sugars during storage of jabuticaba variety 'Pingo de Mel' (Figure 2 and 3D and Appendix A - Table 1A). Brunini et al. (2004) studied the effect of packaging and storage temperature of
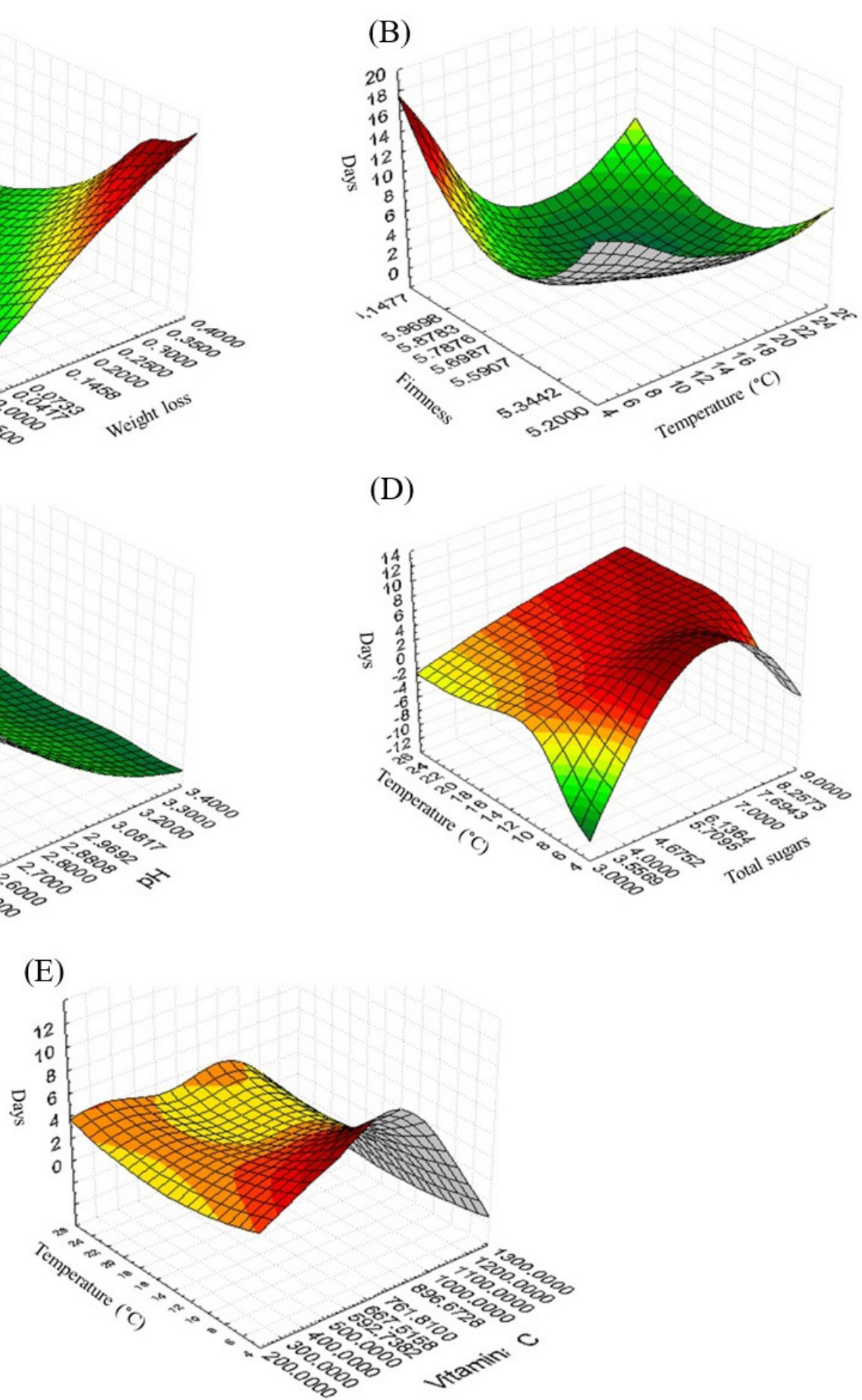

Figure 3. Weight loss (g $100 \mathrm{~g}-1)$ (A), firmness (N) (B), pH (C), total sugars (g 100 g-1) (D) and vitamin C (mg ascorbic acid 100 g-1) (E) of jabuticaba variety 'Pingo de Mel' stored at different temperatures $\left(6^{\circ} \mathrm{C}, 12^{\circ} \mathrm{C}\right.$, and $\left.25^{\circ} \mathrm{C}\right)$ during storage $(0$ to 12 days). 
jabuticaba variety 'Sabará, and also observed an increase in total carbohydrates during the storage period.

No changes in color were observed in jabuticaba fruit in the post-harvest, demonstrating that the treatments did not interfere in the color intensity of the peel, corroborating the studies of Brunini et al. (2004). According to Lima et al. (2013), color changes in the fruit epidermis is related to the degradation of chlorophyll and synthesis of other pigments, such as anthocyanins and carotenoids. Thus, the maintenance of color in jabuticaba may be due to the fruit were harvested at 30 days after anthesis (full ripening), representing the physiological development, with no degradation of chlorophyll and synthesis of anthocyanins.

A reduction of vitamin $\mathrm{C}$ content was also observed during storage, which was also affected by the storage temperature, as can be seen in Figure 3E and Appendix A - Table 1A. Similar behavior was observed by Agostini et al. (2009), who evaluated jabuticaba variety 'Paulista', and also found that the storage conditions led to a reduction of vitamin $\mathrm{C}$, which was higher for the fruit stored at room temperature, probably because the refrigeration process inhibited the oxidative reactions, and delayed the physiological processes, which leads to a reduction of aroma, flavor, and texture, among other attributes.

The antioxidant activity of all extracts (ether, ethanol, and aqueous) determined by both methods was analyzed through PCA, with an increase during the storage period. Taiz \& Zeiger (2006) reported an increase in the phenolic compounds and antioxidants during fruit development and storage, which can often be related to the biotic and abiotic stresses that induce the secondary metabolism of fruit. The increase in these levels has great importance from the nutritional point of view, since several authors have reported a possible role in the prevention of many diseases associated with oxidative stress, such as cancer, cardiovascular and other chronic diseases (Cavalcanti et al., 2011; Lima et al., 2011).

The present study highlighted the cold storage as an important preservation method for post-harvest storage of jabuticaba variety 'Pingo de Mel', once little or no changes were observed in fruit stored for 12 days at $6^{\circ} \mathrm{C}$. Despite the absence of statistical significance, it is believed that the application of calcium chloride along with the reduction of temperature has influenced the increase in the useful life of jabuticaba, since according to Pinheiro et al. (2005), the application of calcium salts in the fruits can increase the levels of this element in the tissues, providing greater resistance in the cell wall and increase the useful life of the fruits. The increase in cell wall resistance hinders the action of pectic enzymes, promoting greater cell integrity and, consequently, lower physiological disorders, as observed in the fruits of jabuticaba var. Pingo de mel.

\section{Conclusion}

The use of the different calcium chloride concentrations did not contribute to the increase in the storage period of jabuticabas variety 'Pingo de Mel'. However, the refrigeration temperature at $6{ }^{\circ} \mathrm{C}$ was a viable alternative for storage for 12 days, maintaining the fruit quality.

\section{Acknowledgements}

The authors are grateful to FAPEG (Research Foundation of the State of Goías, Brazil) for the concession of a scholarship to Lismaíra Gonçalves Caixeta Garcia and to the Fazenda e Vinícola Jabuticabal for donating the fruit used in the research.

\section{References}

Agostini, J. S., Candido, A. C. S., Teodósio, T. K. C., Rodrigues, J. N., Garcete, G. J., \& Scalon, S. P. Q. (2009). Atmosfera modificada e condições de armazenamento nas características físico-químicas de jabuticabas da cultivar 'paulista'. Ciência Rural, 39(9), 2601-2608. http://dx.doi.org/10.1590/S0103-84782009005000205.

Arruda, M. C., Fischer, I. H., Jeronimo, E. M., Zanette, M. M., \& Silva, B. L. (2011). Postharvest of yellow passion fruit: effect of chemicals and storage temperature. Semina: Ciências Agrárias, 32(1), 201-208. http://dx.doi.org/10.5433/1679-0359.2011v32n1p201.

Ascheri, D. P. R., Ascheri, J. L. R., \& Carvalho, C. W. P. (2006). Caracterização da farinha de bagaço de jabuticaba e propriedades funcionais dos extrusados. Food Science and Technology, 26(4), 897-905. http://dx.doi.org/10.1590/S0101-20612006000400029.

Association of Official Analytical Chemists - AOAC. (2010). Official methods of analysis (18th ed.). Washington: AOAC.

Azzolini, M., Jacomino, A. P., \& Bron, I. U. (2004). Índices para avaliar qualidade pós-colheita de goiabas em diferentes estádios de maturação. Pesquisa Agropecuária Brasileira, 39(2), 139-145. http:// dx.doi.org/10.1590/S0100-204X2004000200006.

Barreto, C. F., Silva, P. S., Kirinus, M. B. M., Schiavon, C. R., Malgarin, M. B. M., \& Fachinello, J. C. (2016). Armazenamento refrigerado de pêssegos 'maciel' de plantas conduzidas em diferentes porta-enxertos. Revista Iberoamericana de Tecnología Postcosecha, 17(2), 254-261.

Bitter, T., \& Muir, H. M. (1962). A modified uronic acid carbazole reaction. Analytical Biochemistry, 4(4), 330-334. http://dx.doi. org/10.1016/0003-2697(62)90095-7. PMid:13971270.

Brunini, M. A., \& Coelho, C. V. (2004). Influência de embalagens em jabuticabas 'Sabará. Revista Nucleus, 3(1), 81-88.

Brunini, M. A., Oliveira, A. L., Salandini, C. A. R., \& Bazzo, F. R. (2004). Packaging and temperature influences on the storage of jaboticaba (Myrciaria jabuticaba (Vell) Berg) fruits cv. 'Sabará. Food Science and Technology, 24(3), 378-383. http://dx.doi.org/10.1590/S010120612004000300013.

Carneiro, J. O., Souza, M. A. A., Rodrigues, Y. J. M., \& Mapeli, A. M. (2015). Effect of temperature and the use of packing in the post harvest conservation of Eugenia dysenterica dc. fruits. Revista Brasileira de Fruticultura, 37(3), 568-577. http://dx.doi.org/10.1590/01002945-157/14.

Cavalcanti, R. N., Veggi, P. C., \& Meireles, M. A. A. (2011). Supercritical fluid extraction with a modifier of antioxidante compounds from jabuticaba (Myrciaria cauliflora) byproducts: economic viability. Procedia Food Science, 1, 1672-1678. http://dx.doi.org/10.1016/j. profoo.2011.09.247.

Chen, F., Liu, H., Yang, H., Lai, S., Cheng, X., Xin, Y., Yang, B., Hou, H., Yao, Y., Zhang, S., Bu, G., \& Deng, Y. (2011). Quality attributes and cell wall properties of strawberries (Fragaria annanassa Duch.) under calcium chloride treatment. Food Chemistry, 126(2), 450-459. http://dx.doi.org/10.1016/j.foodchem.2010.11.009. PMid:25212155.

Chitarra, M. I., \& Chitarra, A. B. (2005). Pós-colheita de frutos e hortaliças: fisiologia e manuseio (2. ed.). Lavras: UFLA. 
Conway, W. S., Sams, C. E., Mcguire, R. G., \& Kelman, A. (1992). Calcium treatment of apples and potatoes to reduce postharvest decay. Plant Disease, 76(4), 329-334. http://dx.doi.org/10.1094/PD-76-0329.

Damiani, C., Vilas Boas, E. V. B., Pinto, D. M., \& Rodrigues, L. J. (2008). Influence of different temperatures in maintenance of quality of fresh-cut Pequi. Ciência e Agrotecnologia, 32(1), 203-212. http:// dx.doi.org/10.1590/S1413-70542008000100030.

Dische, Z. (1962). General color reaction. In R. L. Whistler \& M. L. Wolfram (Eds.), Carbohydrate chemistry (pp. 447-512). New York: Academic Press.

Drehmer, A. M. F., \& Amarante, C. V. T. (2008). Conservação pós-colheita de frutos de araçá-vermelho em função do estádio de maturação e temperatura de armazenamento. Revista Brasileira de Fruticultura, 30(2), 322-326. http://dx.doi.org/10.1590/S0100-29452008000200009.

Kays, S. (1997). Postharvest physiology of perishable plant products. Georgia: Exon Press.

Lima, A. J. B., Corrêa, A. D., Alves, A. P. C., Abreu, C. M. P., \& DantasBarros, A. M. (2008). Chemical characterization of the jabuticaba fruits (Myrciaria cauliflora Berg) and their fractions. Archivos Latinoamericanos de Nutricion, 58(4), 416-421. PMid:19368305.

Lima, A. J. B., Corrêa, A. D., Saczk, A. A., Martins, M. P., \& Castilho, R. O. (2011). Anthocyanins, pigment stability and antioxidant activity in jabuticaba [Myrciaria cauliflora (Mart.) O. Berg]. Revista Brasileira de Fruticultura, 33(3), 877-887. http://dx.doi.org/10.1590/ S0100-29452011000300023.

Lima, C. S. M., Severo, J., Andrade, S. B., Affonso, L. B., Rombaldi, C. V., \& Rufato, A. R. (2013). Qualidade pós-colheita de Physalis sob temperatura ambiente e refrigeração. Revista Ceres, 60(3), 311-317. http://dx.doi.org/10.1590/S0034-737X2013000300002.

Martins, R. N., Dias, M. S. C., Villas Boas, E. V., \& Santos, L. O. (2007). Refrigerated storage of 'Prata Anã' banana originating from 16, 18 e 20 week-old bunches. Ciência e Agrotecnologia, 31(5), 1423-1429. http://dx.doi.org/10.1590/S1413-70542007000500023.

McCready, P. M., \& McComb, E. A. (1952). Extration and determination of total pectin material in fruits. Analytical Biochemistry, 24(12), 1586-1588.

Melchior, S. J., Custódio, C. C., Marques, T. A., \& Machado, N. B. No. (2006). Colheita e armazenamento de sementes de gabiroba (Campomanesia adamantium Camb. - Myrtaceae) e implicações na germinação. Brazilian Seed Journal, 28(3), 141-150.

Melo, A. P. C., Fernandes, P. M., Venturoli, F., Silva-Neto, C. M., \& Rubio, A. No. (2015). Morphoagronomic characterization of tomato plants and fruit: a multivariate approach. Advances in Agriculture, 2015, 1-6. http://dx.doi.org/10.1155/2015/572321.

Mota, W. F., Salomão, L. C. C., Pereira, M. C. T., \& Cecon, P. R. (2002). Influência do tratamento pós-colheita com cálcio na conservação de jabuticabas. Revista Brasileira de Fruticultura, 24(1), 49-52. http:// dx.doi.org/10.1590/S0100-29452002000100011.

Pinheiro, A. C. M., Vilas Boas, E. V. B., \& Lima, L. C. (2005). Influência do $\mathrm{CaCl}_{2}$ sobre a qualidade pós-colheita do abacaxi cv. Pérola. Food Science and Technology, 25(1), 32-36. http://dx.doi.org/10.1590/ S0101-20612005000100006.

Pulido, R., Bravo, L., \& Saura-Calixto, F. (2000). Antioxidant activity of dietary polyphenols as determined by a modified ferric reducing/ antioxidant power assay. Journal of Agricultural and Food Chemistry, 48(8), 3396-3402. http://dx.doi.org/10.1021/jf9913458. PMid:10956123.

Rufino, M. S. M., Alves, R. E., Brito, E. S., Morais, S. M., Sampaio, C. G., Perez-Jimenez, J., Saura-Calixto, F. D. (2006). Metodologia científica: determinação da atividade antioxidante total em frutas pelo método de redução do ferro (FRAP). Fortaleza: Embrapa Agroindústria Tropical. Comunicado técnico.

Rufino, M. S. M., Alves, R. E., Brito, E. S., Morais, S. M., Sampaio, C. G., Perez-Jimenez, J., Saura-Calixto, F. D. (2007). Metodologia cientifica: determinação da atividade antioxidante total em frutas pela captura do radical livre ABTS.+. Fortaleza: Embrapa Agroindústria Tropical. Comunicado técnico.

Sanches, A. G., Silva, M. B., Moreira, E. G. S., Santos, E. X., \& Tripoloni, F. M. (2017). Extensão da vida útil de pitangas submetidas ao tratamento com cloreto de cálcio. Acta Iguazu, 6(1), 45-58.

Silva, W. B., Silva, G. M. C., Silva, L. R., Waldman, W. R., \& Oliveira, J. G. (2015). Tratamento com cloreto de cálcio na pós-colheita retarda o desverdecimento e a perda de firmeza do mamão UENF/ CALIMAN01. Revista Brasileira de Fruticultura, 37(3), 588-599. http://dx.doi.org/10.1590/0100-2945-158/14.

Souza, P. A., Silva, G. G., Morais, P. L. D., Santos, E. C., Aroucha, E. M. M., \& Menezes, J. B. (2009). Vida útil pós-colheita de frutos de bilimbi (Averrhoa bilimb L.) armazenados sob refrigeração. Revista Brasileira de Fruticultura, 31(4), 1190-1195. http://dx.doi.org/10.1590/ S0100-29452009000400037.

Strohecker, R., \& Henning, H. M. (1967). Análises de vitaminas: métodos comprovados. Madrid: Paz Montolvo.

Taiz, L., \& Zeiger, E. (2006). Plant physiology (4th ed). Sunderland: Sinauer Associates.

Velho, A. C., Amarante, C. V. T., Argenta, L. C., \& Steffens, C. C. (2011). Influence of storage temperature on postharvest quality of feijoas. Revista Brasileira de Fruticultura, 33(1), 14-20. http://dx.doi. org/10.1590/S0100-29452011005000016.

Vilas Boas, E. V. B. (2002). Qualidade de alimentos vegetais. Lavras: UFLA/FAEPE.

Wu, S. B., Dastmalchi, K., Long, C., \& Kennelly, E. J. (2012). Metabolite profiling of jaboticaba (Myrciaria cauliflora) and other dark-colored fruit juices. Journal of Agricultural and Food Chemistry, 60(30), 7513-7525. http://dx.doi.org/10.1021/jf301888y. PMid:22809264. 


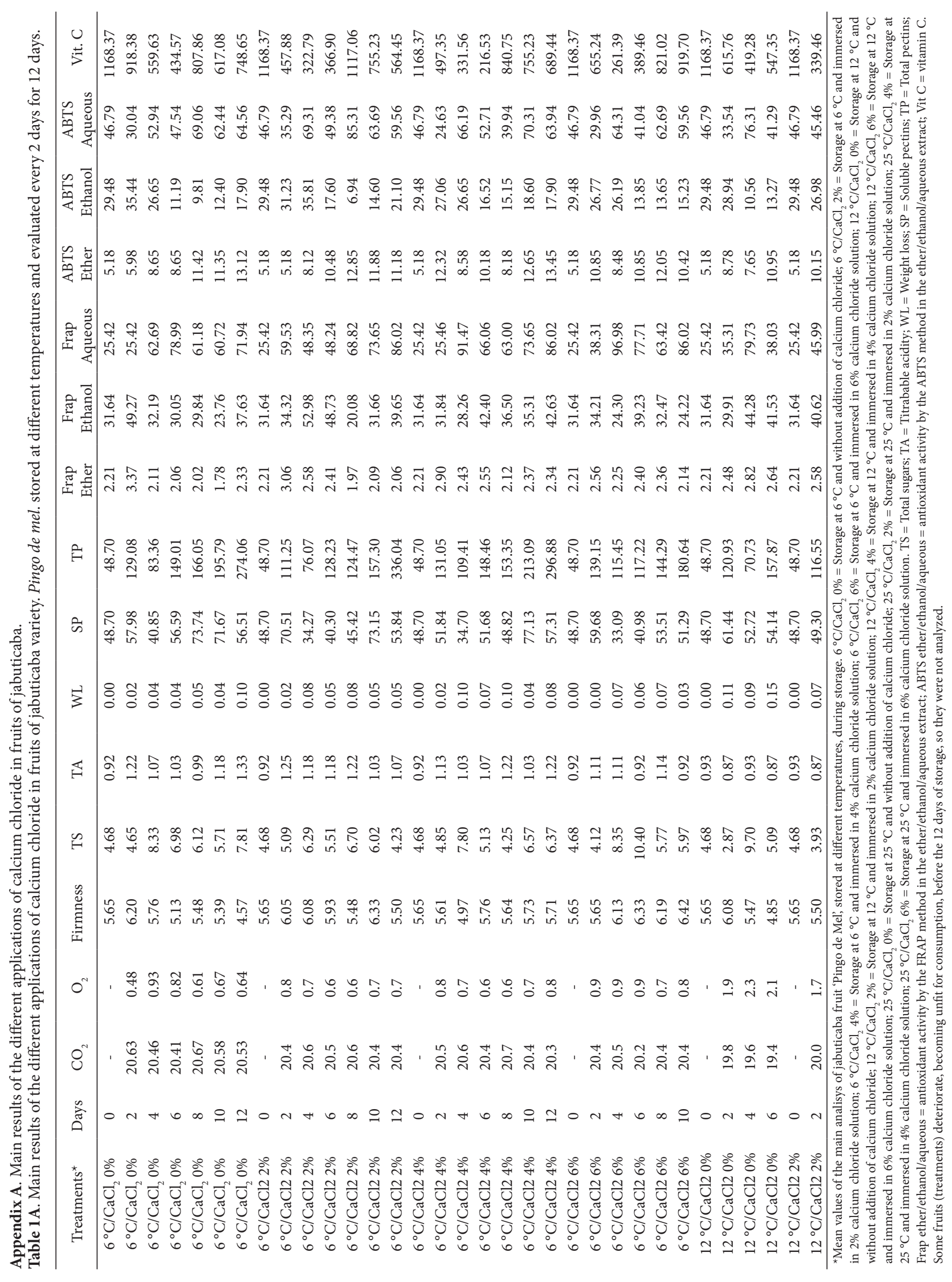




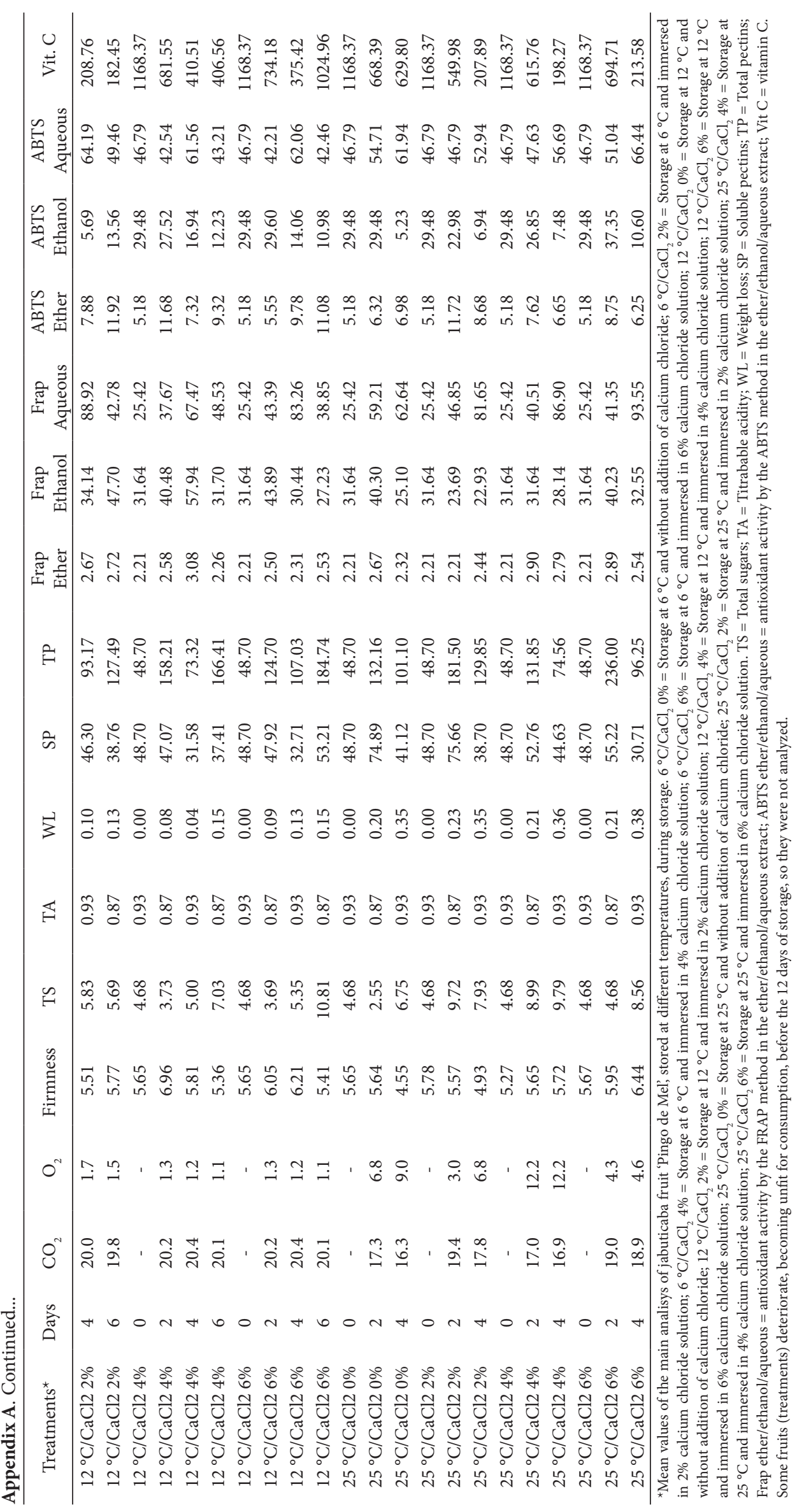

